Journal of Engineering and Applied Sciences 15 (1): 273-278, 2020

ISSN: 1816-949X

(C) Medwell Journals, 2020

\title{
An Analysis Study on the Intellectual Property Regulation in Indonesia: Focusing on the Record of the Intellectual Property Licensing Agreements
}

\author{
${ }^{1}$ Abd. Thalib, ${ }^{2}$ Sharifah Zarina Syed Zakaria, ${ }^{3}$ Kadir Arifin and ${ }^{4}$ Muhammad Rizal Razman \\ ${ }^{1}$ Faculty of Law, Universitas Islam Riau, Jalan Kaharuddin Nasution, \\ No. 113, Simpang Tiga Marpoyan, 28284 Pekanbaru, Riau, Indonesia \\ ${ }^{2}$ Research Centre for Environmental, Economic and Social Sustainability (KASES), \\ Institute for Environment and Development (LESTARI), Universiti Kebangsaan Malaysia, \\ 43600 UKM Bangi, Selangor, Malaysia \\ ${ }^{3}$ Social, Environmental, Developmental Sustainability Research Centre (SEEDS), \\ Faculty of Social Sciences and Humanities (FSSK), Universiti Kebangsaan Malaysia, \\ 43600 UKM, Bangi, Selangor, Malaysia \\ ${ }^{4}$ Research Centre for Sustainability Science and Governance (SGK), \\ Institute for Environment and Development (LESTARI), Universiti Kebangsaan Malaysia, \\ 43600 UKM Bangi, Selangor, Malaysia
}

\begin{abstract}
This study aimed to analyze the Decree of Ministry of Law and Human Rights No. 8 Year 2016 (the "Regulation") on the record of Intellectual Property (IP) Licensing Agreements. As we have indicated, not only the Regulation of Government of the Republic of Indonesia No. 36 of 2018 but also the Decree of Ministry of Human Rights No. 8 of 2016, has failed to create technology transfer for Indonesia. Even though the transfer of technology is strongly campaigned as a principal means of relieving world poverty, there is no reliable and credible evidence that shows a significant correlation between record of IP licensing agreements under the Decree of Ministry of Law and Human Rights No. 8 Year 2016 and technology transfer under the IP regime and the collective mastery of a nation to access Information, knowledge and Technology (INT) effectively in order to improve the quality of people's lives.
\end{abstract}

Key words: Record of IP licensing agreements, technology transfer, Indonesia, information, quality

\section{INTRODUCTION}

Intellectual property is the product of the human intellect including creativity concepts, inventions, industrial models, trademarks, songs, literature, symbols, names and brands. Intellectual property rights do not differ from other property rights. They allow their owner to completely benefit from his/her product which was initially an idea that developed and crystallized. They also entitle him/her to prevent others from using, dealing or tampering with his/her product without prior permission from him/her. He/she can in fact legally sue them and force them to stop and compensate for any damages.

Intellectual property can be divided into two categories: Industrial property which includes: Inventions (patents), trademarks, industrial designs and models and geographic indications of source. Copyright, which includes: literary and artistic works, namely novels, poems, plays, films, musicals, cartoons, paintings, photographs, statues and architectural designs. In Indonesia, a patent is a temporary monopoly granted by the state in respect of an invention. The owner of a patent, the patentee shall have exclusive rights and monopoly to exploit or use commercially his patent individually or by giving his consent to other persons to make, sell, lease, deliver, use, supply for sale or lease or delivery of the products for which patent has been granted (Article 19 (1) of the Indonesian Patents Act (IPA), No. 13 of 2016, hereinafter IPA No. 13 of 2016). He may transfer any one or more of these rights either wholly or partly to any other person (Article 74 of the IPA). He can also license its use on his freedom to deal with the patent completely as he wishes (Article 76 of the IPA). It is different from some fields of property. However, there are certain limitations on his freedom to deal with the patent completely as he wishes. A license is an official permission or permit to do, use or own something (as well as the document of that permission or permit) (Raysman et al., 2018). In Indonesia, Patent Holder reserves the right to grant a license to other parties under a licensing agreement either exclusive or non-exclusive license to carry out the acts referred to in Article 19. License Agreement referred 
to in paragraph (1) May cover all or partly acts as referred to in Article 19. License Agreement referred to in paragraph and (2) Shall apply during the term of the licensing agreement and applicable in the territory of the Republic of Indonesia (Article 69 of the IPA, 2016).

In this connection, as far as patent licensing agreement is concern, a license agreement shall not contain provisions that may directly or indirectly be detrimental to the economy of Indonesia or contain restrictions which hamper the capabilities of the Indonesian people to master and develop technology in general and particularly with respect to invention for which patent has been granted (Article 78 of the IPA, 2016). The request for recordation of any license agreement which contains provisions as referred to Article 78 must be refused by the Directorate General (Article 79 (3) of the IPA, 2016). A license agreement shall be recorded and published, with the payment of a fee (Article 79 (1) of the IPA, 2016). In the event a license agreement is not recorded at the Directorate General as referred to in paragraph (1), such license agreement will have no legal effects on a third party (Article 79 (2) of the IPA, 2016). Further provisions on the recording agreement license are regulated by the Minister (Article 80 of the IPA, 2016).

In Indonesia, as in many other countries, IP agreements must be registered in order to be fully effective. Until now, registration has not been possible in the absence of registration guidelines or regulations. This situation has at last been rectified: The long-awaited regulations were issued late last 2 year. On 24 February, 2016, the Ministry of Law and Human Rights issued Ministerial Decree No. 8 of 2016 concerning the Requirement and Procedure of Intellectual Property License Record which serves as an implementing regulation for the record of IP licenses. Further on 27 July 2018 President of Republic of Indonesia issued the Regulation No. 36 of 2018 on the Record of IP Licensing Agreements. The Decree provides that record applications must be accompanied by: A copy of the license agreement (It may be possible to record a simple confirmatory agreement setting out key terms without closing confidential terms), a copy of the registration certificate; an original power of attorney, the record fees (which are as stipulated in Government Regulation No. 45 of 2014 concerning Types and Tariffs of non-tax state revenue applicable to the Ministry of Law and Human Rights) and a special statement form confirming that the recorded license agreement relates to intellectual property. The application will be examined for formalities. If there are any issues, the applicant will be notified and given 10 days to comply, failing which the application will be considered withdrawn. If all requirements are complied with the license agreement will be recorded and published on the website of the Directorate General of IP (Article 7 of the Ministerial Regulation, 2016).

There is no indication at present as to whether the license agreement itself will be examined substantively or the requirements as to the form or contents of the license agreement (Thalib, 2016). On the other hand, whilst there is no deadline by which a license must be recorded, we recommend filing an application for record as soon as possible to ensure that the licensee can enjoy the full benefit of the rights in the trade mark (Thalib, 2016). Therefore, this study is aimed to analyze with regard to the industrial property rights with the emphasis on the record of Intellectual Property (IP) licensing agreements, especially about patent license contract.

Among many factors to assist in providing an appropriate level of Transfer of Technology (TT), there are in general two ways of getting Foreign technology transferred to developing countries: Its sale to local enterprises by licensing (patented and unpatented know-how) and its transfer by means of direct investment. This study assesses the adequacy of TT in Indonesia not only under the statutory Patent Laws, provided by the Indonesian Patents Act 2016, the Decree of Ministry of Law and Human Rights No. 8 of 2016 on the record of IP Licensing Agreements but also from the government policies. Within the confines of the Indonesian Patents Act 2016, the present study not only examines the specific provisions on TT under the defensive registration provision in Sections 78, 79 (3) and 80 of the Indonesian Patents Act but also the Decree of Ministry of Law and Human Rights No. 8 of 2016 on the record of IP Licensing Agreements under Articles 2 (2), 4 and 5.

The research methodology employed in this study is predominantly library research. Relevant articles, books, local and international law reports, reviews, conference and seminar papers constituted the main source of information for this study.

\section{INDONESIAN PATENTS LAW NO. 13 OF 2016}

Among many factors to assist in providing an appropriate level of Transfer of Technology (TT) as indicated above, there are in general two ways of getting Foreign technology transferred to developing countries: Its sale to local enterprises by licensing (patented and unpatented know-how) and its transfer by means of direct investment. A system of license of right has been evolved in the patent laws of some countries to overcome the inherent deficiencies in the system of compulsory licensing. This system is also known as automatic licensing system. System of licenses of right is a voluntary as well as non-voluntary restriction on the exclusive monopoly of the patentee's right in the public 
interest. Voluntary in the sense that under this system a patentee may safeguard his patent from a compulsory license application or revocation for non-use by voluntarily applying to the patent office at any time after grant of patent to have the patent endorsed with the word "licenses of right". It is non-voluntary in the sense that after the lapse of particular period (generally it is three years) from the date of grant of patent, the government can apply to the controller to have a patent endorsed with the word "licenses of right". Additionally there is also third type of this system where the endorsement of a class of patents with the words "license of right" is made by statute itself (Thalib, 2014).

Further, with regard to license the patentee shall be entitled to give it to another person pursuant to a license agreement (Article 76 of the IPA, 2016). The conditions of the license including the amount of remuneration payable to the patentee (sometimes it is called royalties), is determined in the absence of agreement by an authority designated by the law for this purpose. Moreover, unless otherwise agreed, a patent holder may continue to perform by himself or give a license to any other third parties to perform the acts referred to in Article 16 which shall be effective during the term of the license.

This system may be specially attractive to developing countries because once a patent is thrown open to license of right, it will no longer depend on the will of the owner of the patent whether the patent will be exploited in the country, anybody can obtain a license and on the basis of that license work the patented invention in the country. However, this system has also been criticized by saying that, "the disadvantage of this system is that prospective licensees hesitate to obtain such a non-exclusive license since competitors can obtain the same at any time (Ladas, 1975). A license may be expressed, implied or statutory, it may exclusive, non-exclusive or limited. An exclusive license is defined under Article 76 (1). Such a license excludes all other persons including the patentee from the right to use the invention. In a limited license, the limitation may arise as to persons, place, time, use, manufacture and sale.

The agreement between the parties concerned must be reduced to the form of a document embodying all the terms and conditions governing their rights and obligations. An application for registration of such document must be registered to the directorate general of intellectual property rights which shall be recorded and published with the payment of a fee. Where a licensing agreement is not recorded, said licensing agreement will not have legal effects on a third party (Article 79 (2) of the IPA, 2016). Furthermore, Article 78 however, excludes certain clauses from such licenses, declaring them to be invalid. The two sorts of clauses are: Provision which is directly or indirectly detrimental to the Indonesian economy and certain limitations obstructing the capability of the Indonesian people to master and develop the technology generally connected with the patented invention and particularly the invention for which the patent has been granted.

As far as regulations system on the transfer of technology in Indonesia is concerned, apart from Patents Law, 2016 as indicated above, under Articles 11 and 12 Investment Law, No. 25 of 2007 mentioned that: "Enterprises with Foreign capital are obliged to arrange and/or to provide facilities for training and education at home or abroad for Indonesian nationals in an organized way and with a set purpose in order that the alien employees may gradually be substituted by Indonesian ones". In addition, the activity program may be organized by the employers or third-party services may be utilized (Article 8 of the Presidential Decree No. 75 of 1955). The non performance of this obligation results in employers employing Foreign worker(s) to pay a compulsory educational and training contribution. Such contributions will be used to fund the government's manpower education and training (Minister of Manpower Regulation No. 143 A/MEN/1991 on Educational and Training Obligatory Payments). Beside it, in the oil and gas sector, contractors of oil and gas production sharing contracts are required to provide an educational and training program for all Indonesian employees (Article 12 of the Government Regulation No. 35 of 1994). On this subject, the Elucidation of the Oil and Gas Law No. 22 of 2001 does not give further explanation. It should be noted, however, that the general policy towards the skill problem of Indonesian national manpower is that efforts should be made to enhance knowledge, improve skill, augment the ability to organize and manage. In pursuance of this general policy, we may emphasize that within the framework of mineral oil and gas mining, the above mentioned efforts should also be made by the government such as the state oil enterprise.

On the one hand, these laws were intended to invite private Foreign capital to be invested in projects which will contribute to the healthy development of Indonesia's economy. Pursuant to the law on industrial affairs, selection and transfer of Foreign industrial technology which is strategic in nature and needed for the development of domestic industry. On the other hand, as indicated above that the license agreement between the parties concerned must be reduced to the form of a document embodying all the terms and conditions governing their rights and obligations, hence such document must be registered to the directorate general of intellectual property rights which shall be recorded and announced with the payment of a fee. Where, a licensing agreement is not recorded, said licensing agreement will not have legal effects on a third party. Otherwise, further provisions concerning licensing agreements shall be regulated by a government regulation (Article 80 of the IPA, 2016). 


\section{DECREE OF MINISTRY OF LAW AND HUMAN RIGHTS NO. 8 OF 2016}

Regulation on record of ip licensing agreements (Indonesia): Indonesia has set out, for the first time, regulations on the procedures to record license agreements for trademarks, patents, copyright and industrial designs. Although, there was previously a requirement to record license agreements, recordation was not actually possible in practice due to a lack of implementing regulations and guidelines.

In the past, instead of recording IP license agreements, patent or trademark owners would file their license agreements to obtain an official stamp on the documents as evidence of good faith. Trademark owners went ahead with filing their license agreements, despite the fact that it was unclear whether or not they were enforceable against third parties. Filing a license agreement, however, was not considered as official recordation, because the process should have involved: Making a request to record a license agreement at the Directorate General of Intellectual Property (DGIP); Paying the prescribed fees and obtaining an examination of the application to record the license agreement. An IP license agreement would only be considered as officially recorded if these steps were properly taken and successfully fulfilled but this was not previously possible due to a lack of implemented regulations and guidelines.

In an effort to curb these problems, on February 24, 2016, the ministry of law and human rights issued a ministerial regulation on the requirements and procedures for recordation of intellectual property license agreements (ministerial regulation). This is an important development because without recordation, license holders do not have the right to enforce their IP rights under a license agreement against infringers. In fact, IP license agreements that are not recorded are not recognized by any third party (Article 15 (4) of the Government Regulation No. 36 of 2018). For example, a licensee's use of a registered mark under an unrecorded license agreement is not considered as actual "use" by the IP owner. This can lead to the cancellation of the trademark's registration based on non-use (after three consecutive years), even if the mark was used by a non-recorded licensee.

Under the ministerial regulation, a recorded IP license agreement will be valid across the entire territory of the Republic of Indonesia, unless agreed otherwise (Article 7 (2) of the Government Regulation No. 36 of 2018, for a period of 5 years (Article 10 (1) of the Government Regulation No. 36 of 2018 (Article 10 (1) of the Government Regulation No. 36 of 2018. Although, the licensor and licensee may agree on a longer term of validity, recordation of the license agreement would only be valid for five years and it must not exceed the term of protection of the concerned intellectual property
(Article 17 (1) of the Government Regulation No. 36 of 2018. Recordation can be extended (Article 17 (2) of the Government Regulation No. 36 of 2018, subject to the payment of fees in accordance with the provisions of applicable laws (Article 10 (4) (d) of the Government Regulation No. 36 of 2018. In addition to licensing whole trademark registrations, it is possible to license part of the goods or services of a registration. It is also not mandatory for a licensor to grant an exclusive license to only one licensee and the licensor may continue to use the licensed IP or grant additional licenses to other parties, unless agreed otherwise. Sublicenses by licensees are also permitted.

The ministerial regulation introduces a number of requirements and procedures for the recordation of IP license agreements. Recordation can be done either electronically through the DGIP's official website or by submitting a hard copy version of the required documents to the DGIP. In addition to the basic documents that are required, such as a power of attorney and a copy of the IP registration certificate, a copy or proof of the license agreement must also be submitted to the DGIP. In interpreting a "copy or proof" of the license agreement, it is presumed that a short-form license agreement can be submitted instead of a copy of the original license agreement, in order to maintain party confidentiality and reduce translation costs. A short-form license agreement should be submitted in both English and Indonesian because under the law, Indonesian is the official language for transactions and commercial documents.

Under the ministerial regulation, the DGIP will examine each recordation application to determine the completeness of the required documents within ten working days after an application is filed. At this point, it is unknown whether the DGIP would be able to complete the examination within the stipulated period of 10 days because for other types of recordation such as record of assignment or record of name/address change, it normally takes the DGIP more than 1 year to issue a certificate of record.

After examining a recordation application, if the DGIP determines that the required documents are complete, the minister will record the license agreement in the general register for each respective type of IP. On the other hand, if certain required documents are missing, the application will be returned to the applicant to provide the required documents within a prescribed period. If the deadline is not met, the recordation will be abandoned. It is, however, possible to re-file the application to record the license agreement but this comes with prescribed official fees. Registrants who submitted a license agreement to the DGIP prior to the ministerial regulation's enactment should re-file their agreement in accordance with the new requirements and procedures. This will ensure greater legal certainty and the recognition of license agreements by third parties. 
Ultimately, as indicated above with regard to the government regulation as far as IP license agreements is concern, although, recordation of license agreements to the DGIP is not compulsory without registration it may be difficult to remit royalty payments out of Indonesia: record certificate may be required by the bank at the time it remits royalty payments overseas. The point of view here, for those who are unwilling to apply to register their IP license contract to the DGIP is there any sanction for them? How about their contracts those bring disadvantages of economic interest of nation as well as to challenge the capability of technology patent? Who authorizes to evaluate the contracts? There should be an institution to monitor as well as to evaluate this regard to their license IP contracts.

On the one hand, these laws were intended to invite private Foreign capital to be invested in projects which will contribute to the healthy development of Indonesia's economy. Pursuant to the law on industrial affairs, selection and transfer of Foreign industrial technology which is strategic in nature and needed for the development of domestic industry. On the other hand, as indicated above that the license agreement between the parties concerned must be reduced to the form of a document embodying all the terms and conditions governing their rights and obligations. Hence, such document must be registered to the directorate general of intellectual property rights which shall be recorded and announced, with the payment of a fee. Where a licensing agreement is not recorded, said licensing agreement will not have legal effects on a third party. Otherwise, further provisions concerning licensing agreements have been regulated by a government regulation. In this context, at present, such government regulation is not valuable yet. It means, in this regard that the basic philosophy of the contractual arrangements, i.e., technology transfer from Foreign companies to Indonesian nationals is not effective.

No doubt, that the primary objective of a licensee in entering into a technology license agreement includes the acquisition of a developed and tested industrial process without having to bear the risks, delay and expense of its development. For licensees in developing countries, the unavailability of facilities or resources for Research and Development (R\&D) often renders the licensing of Foreign technology rights the only means of obtaining them. Even if the licensee were to embark upon the necessary research, the risk of failure is compounded by the risk that a rival enterprise may be able to obtain industrial property protection in relation to the relevant technology. 'Licensing in' may assist a licensee after a profitable exploitation period, under the name or mark of the licensor, to aggregate the financial, technical and commercial means necessary to initiate its own research program (Thalib, 2016).
In Indonesia a major 'unpackaged' (non-equity) mode of technology transfer from advanced country firms to Indonesian firms has been Technical Licensing Agreements (TLAs). Although no quantitative data are available on the number of these TLAs, circumstantial evidence indicates that these TLAs often involve the transfer of older and mature technologies that do not offer the recipient country a long-term competitive advantage in the global market. However, for a late-industrializing economy like Indonesia, acquiring and mastering these older technologies first is a good way to develop the important basic Industrial Technological Capabilities (ITCs), namely the production, investment and adaptive capabilities (Thalib, 2016).

Furthermore, China, in order to protect a patent right, regulate the license acts and promote the proper usage of the patent right, the State Intellectual Property Office of China (i.e., the "SIPO") enacted, under the Chinese Patent Law and Contract Law and released the Administrative Measures for Recording a License Agreement ("Measures") which took effect as of August 1, 2011. According to the measures, the patent owners could record license agreements officially in order to safeguard their interests over the licensed Chinese patents in China (Qi, 2017).

Nowadays, more and more license agreements are concluded due to the various transnational cooperation and then may need to be recorded with the SIPO. Though the above measures have been implemented for several years, there still exists some typical neglect by licensors in practice which lead to unsuccessful record acts before the SIPO. Taking those typical situations into consideration, we think the following points in recording a license agreement at the SIPO shall be kept in mind by all patent owners, especially by Foreign companies and individuals (Qi, 2017).

Qi (2017) stipulates: "We should mention that it is not compulsory for a licensor, typically a patent owner, to record his license agreement under the Chinese Patent Law. The license agreement shall be concluded under the contract law in China and takes effect as of the effective date of the agreement. The record is by no means, the condition for the license to be valid in China” (Qi 2017). Nevertheless, the record is beneficial for the sake of the licensor and licensee. For example, after the record, the SIPO will publish the basic data (exclusive of the text of the license agreement) of the recorded license agreement and the publication would go against any third party with good faith. Another example is that when a local intellectual property office handles an administrative conciliation in a patent infringement dispute, the type, duration, royalty and payment methods, etc. of the recorded license, would be taken as the reference for deciding the compensation. Moreover, according to the 
some provisions regarding the applicable laws for injunction issued by the supreme court, Rule 4, Para 2, the certificate of a license agreement record would be served as necessary proof for the interested party to request injunction. For some Chinese licensee, the record of exclusive license against the Chinese patents would be one of the necessary conditions to obtain the qualification as the high and new technology enterprises under the related Chinese laws and regulations with which the Chinese licensee could enjoy many benefits, such as the tax reduction and funding support by the local government (Qi, 2017).

\section{CONCLUSION}

As we have seen above, neither Indonesian patents system nor the regulation of government is effective for the transfer of technology in Indonesia. Even, as far as transfer of technology is concerned, there is no reliable and credible evidence that shows a significant correlation between record of IP licensing agreements under the Decree of Ministry of Law and Human Rights No. 8 Year 2016 and technology transfer under the IP regime and the collective mastery of a nation to access Information, knowledge and Technology (INT) effectively in order to improve the quality of people's lives.

The pattern of inward technology flows for Indonesia seems to be dominated by the use of FDI as the main channel for technology acquisition. In some sense this has been the country's implicit 'technology policy' and the favorable attitude of the government towards FDI has been based to a large extent on the promise of technology that will be brought in as part of the investment package. The government has attempted to use some performance requirements in its regulations to affect more rapid transfers of technology. The regulations have been weak and no specific incentives have been given to encourage FDI that will upgrade local technological capabilities. From time to time there have been calls for government regulation of technology transfer agreements on the grounds that Foreign licensors (technology suppliers) may impose 'unfair' restrictions and conditions in such agreements and that Indonesian firms lack commercial experience in these matters in negotiating with Foreign firms, particularly the Transnational Corporations (TNCs). Hence, government intervention could increase the bargaining power of the local recipients (the Indonesian firms) in their negotiations with the prospective technology suppliers (the Foreign firms).

Another argument against government intervention in negotiations on technical licensing agreements is that Indonesian government officials in general, like government officials elsewhere, do not have the necessary business experience or knowledge about industrial technologies to make informed decisions on the appropriate levels and forms of royalty payments. While royalty payments can often be quite high, restrictions on the amount of royalty payments could lead Foreign licensors to circumvent them by resorting to other means, for instance 'transfer payments', to obtain what they felt was the right amount of royalty payments.

Regulation of technology licensing in Indonesia needs, therefore, to be viewed from a dual perspective. On the one hand, institutional control should ensure that restrictive provisions in agreements that are adverse to the interests of licensees and the economy should be avoided or minimized as far as possible. On the other hand, positive institutional assistance is necessary to promote the inflow of appropriate and essential technology to cover major technological and production gaps. It is only when a judicious balance has been struck between these aspects that licensing of Foreign technology can serve as a really effective instrument for technological growth in Indonesia.

\section{ACKNOWLEDGEMENT}

This study was conducted by using funding from the research projects of the XX-2018-008 and XX-2017-006.

\section{REFERENCES}

Ladas, S.P., 1975. Patents, Trademarks and Related Rights: National and International Protection. Vol. 1, Harvard University Press, Cambridge, Massachusetts, USA., ISBN: 0-674-65775-6, Pages: 2097.

Qi, L., 2017. China: Practical guidance on license agreement recordal at the SIPO. Mondaq, London, UK. http:/www.mondaq.com/china/x/610812/ Patent/Practical+Guidance+On+License+Agreeme $n t+$ Recordal + At + The + SIPO

Raysman, R., E.A. Pisacreta, S.H. Ostrow and K.A. Adler, 2018. Intellectual Property Licensing: Forms and Analysis. Law Journal Press, Philadelphia, Pennsylvania, USA., ISBN: 9781588520869, Pages: 650.

Thalib, A., 2014. Technology transfer in Indonesia: Legal perspective. UUM. J. Legal Stud., 5: 69-85.

Thalib, A., 2016. Technology transfer in Indonesia and China: A comparative study. IUS. Quia Iustum Law J., 23: 251-270. 